\title{
Intestinal Parasitic Infections in Relation to COVID-19 in Baghdad City
}

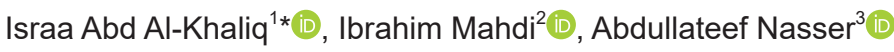 \\ ${ }^{1}$ Department of Microbiology, Al-Kindy College of Medicine, University of Baghdad, Baghdad, Iraq; ${ }^{2}$ Department of Microbiology, \\ PCR Lab, Al-Kindy Teaching Hospital, Baghdad, Iraq; ${ }^{3}$ Department of Microbiology, Consultant Clinic Laboratory, Al-Kindy \\ Teaching Hospital, Baghdad, Iraq
}

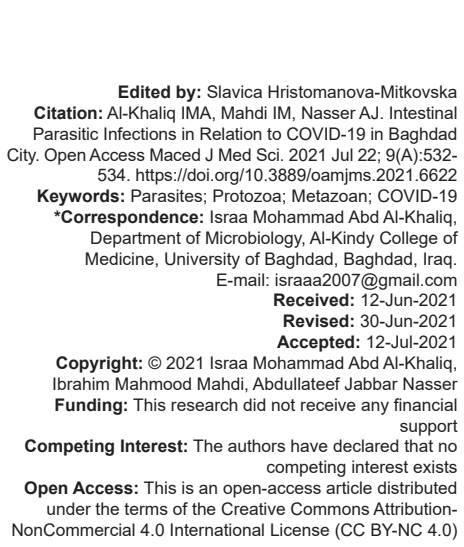

Edited by: Slavica Hristomanova-Mitkovska Edited by: Slavica Hristomanova-Mitkovska
Citation: Al-Khaliq IMA, Mahdi IM, Nasser AJ. Intestinal Parasitic Infections in Relation to COVID-19 in Baghdad City. Open Access Maced J Med Sci. 2021 Jul 22; 9 (A):532534. https://doi.org/10.3889/oamjms.2021.6622 Keywords: Parasites; Protozoa; Metazoan; COVID-19
${ }^{*}$ Correspondence: Israa Mohammad Abd Al-Khaliq "Correspondence: Israa Mohammad Abd Al-Khaliq,
Department of Microbiology, Al-Kindy College of Department of Microbiology, Al-Kindy College of
Medicine, University of Baghdad, Baghdad, Iraq E-mail: israaa2007@gmail.com Revised: 30 -Jun-202 Revised: 3 0-Jun-202
Accepted: 12 -Jul-202 Copyright: ๑ 2021 Israa Mohammad Abd Al-Khaliq, Ibrahim Mahmood Mahdi, Abdullateef Jabbar Nasser Funding: This research did not receive any financial Competing Interest: The authors have declared that no competing interest exists
caccess article distributed Open Access: This is an openactive Commons Attributionunder the terms of the Creative Commons Attribution-
NonCommercial 4.0 International License (CC BY-NC 4.0)

\begin{abstract}
BACKGROUND: COVID-19 is resulted from severe acute respiratory syndrome coronavirus 2, which initiated in China in December 2019. Parasites are efficient immune modulators because their ability to stimulate an immune response in infected persons.

AIM: This study aims to detect if there is a probable relationship between intestinal parasitic infections and COVID-19. METHODS: Ninety patients consulted at Al-Kindy Teaching Hospital (Al-Shifa center) from October 2020 till Apri 2021, confirmed infection with COVID-19 by PCR. Stool examination was done for detecting intestinal parasites.

RESULTS: From 90 patients, males were 63 (70\%), with median age 32 years, while females were 27 (30\%), with age 24-44 years. Asymptomatic patients were $8.1(9 \%)$, patients with moderate symptoms $22.5(25 \%)$ cases, while the rest were $59.4(66 \%)$ cases who required enter to the intensive care unit, with symptoms including cough $(80 \%)$ dyspnea $(74 \%)$, fever $(56 \%)$, headache $(43 \%)$, chest pain $(37 \%)$, sore throat $(35 \%)$, myalgia $(32 \%)$, diarrhea $(27 \%)$, and hemoptysis (3\%).

CONCLUSION: There is inverse relationship between parasitic infection and COVID-19 infections, and it is significant to understand the action between parasites and microbiome, also its function in COVID-19 pathogenicity.
\end{abstract}

\section{Introduction}

There were more than 177 million cases recorded and 38 million deaths till May 2021 [1]. Serious cases, COVID-19 can be complicated by acute respiratory distress syndrome, cardiac injury, sepsis, kidney infection, and also multiorgan failure [2]. Elder also underlying comorbidities as diabetes, hypertension, and cardiac diseases were documented as factors increase the severity of this virus and death [3].

Parasites are efficient immune modulators because their ability to stimulate an immune response in the persons infected by making a balance between responses of pro-inflammatory and responses of antiinflammatory [4].

Parasites infect about 2 billion persons over the world [5]. Metazoan parasites such as Schistosoma, Ascaris, and Enterobius, as well as protozoa such as Giardia, Entamoeba, and Cryptosporidium are the main parasites [6]. Chronic parasitic infections, through host's immune response modulation, proved to change other infections related clinical outcomes [7]. Previous parasitic infections could also modulate host immune reaction to infection with severe acute respiratory syndrome coronavirus 2 (SARS-CoV-2) by harmful or useful effects [8]. Recent researches proved counteractive relationship between occurrences of this viral disease some parasitic infections [9]. The aim of this study was to detect if there is a probable relationship between intestinal parasitic infections and COVID-19.

\section{Materials and Methods}

\section{Study design and participants}

Ninety patients confirmed diagnoses with COVID-19 were consulted atAl-Kindy Teaching Hospital (Al-Shifa center) from October 2020 till April 2021. All patients in this study were from Baghdad, diagnosed according to the WHO procedure [10].

\section{Data collection}

Clinical and laboratory data were collected in questionnaire; COVID-19 patients' data were reviewed. 


\section{Sample collection and RNA extraction}

Ninety patients examined in this study. Nasal pharyngeal and throat swab were collected in viral transporting media tube (VTM-tube) for RNA extraction. RNA extraction processed according to the manufacture use (Viral Line RNA extraction Kit KFFLX, automated German). KingFisher thermos machine has been programmed and used.

\section{Real-time reverse transcription polymerase chain reaction assay (RT-PCR)}

RT-PCR tests of swabs done as described by Wang et al. [11]. The RT-PCR kit (RealLine-SARSCoV-2, BIORON diagnostic German) was used according to the manufacture manual.

The RT-PCR program was as described by manufacture use (RealLine-SARS-CoV-2, BIORON diagnostic), as shown in Table 1. Analytik Jena qTOWER ${ }^{3}$ PCR machine has been programed and used. The data analyzed according to the manufacture manual.

Table 1: Program of RT-PCR

\begin{tabular}{llll}
\hline No. of step & Temperature $\left({ }^{\circ} \mathrm{C}\right)$ & Time & No. of cycles \\
\hline 1 & 35 & $20 \mathrm{~min}$ & 1 \\
2 & 95 & $5 \mathrm{~min}$ & 1 \\
3 & 94 & $10 \mathrm{~s}$ & $50^{*}$ \\
& 64 & $15 \mathrm{~s}^{*}$ & \\
4 & 80 & $1 \mathrm{~s}$ & 1 \\
5 & 10 & Hold & \\
\hline
\end{tabular}

\section{Stool examination}

Confirmed infected patients with this viral infection were examined for intestinal parasitic infections, stool samples were taken from patients, and a wet slide was prepared using normal saline, iodine to demonstrate parasites under light microscope.

\section{Ethical considerations}

Ethical approval obtained from scientific affairs of Al-Kindy College of Medicine.

\section{Results}

According to the signs and symptoms of disease, patients were divided to three categories: Asymptomatic patients were $8.1(9 \%)$, or patients had moderate symptoms $22.5(25 \%)$ cases, while the severe cases were $59.4(66 \%)$ in Table 2. Cough $(80 \%)$, dyspnea $(74 \%)$, fever $(56 \%)$, headache $(43 \%)$, chest pain $(37 \%)$, sore throat $(35 \%)$, myalgia $(32 \%)$, diarrhea $(27 \%)$, and hemoptysis (3\%) as shown in Table 3.
Table 2: Categories and percentage of infected patients with severe acute respiratory syndrome coronavirus 2

\begin{tabular}{lll}
\hline Total patients (90) & & \\
\hline Category & No. & $\%$ \\
\hline Asymptomatic patients & 8.1 & 9 \\
Mild symptoms & 22.5 & 25 \\
Severe disease & 59.4 & 66 \\
\hline
\end{tabular}

Stool examination was done by technicians team specialized in parasitology, showed that there were no parasitic infections in the stool of 89 patients, so there was a negative correlation between intestinal parasitic infections and COVID-19 in patients, results detected only one asymptomatic patient harbored Giardia parasite, as shown in Table 4.

Table 3: Significant symptoms and percentage of infected patients

\begin{tabular}{ll}
\hline Significant symptoms & $\%$ \\
\hline Cough & 80 \\
Dyspnea & 74 \\
Fever & 56 \\
Headache & 43 \\
Chest pain & 37 \\
Sore throat & 35 \\
Myalgia & 32 \\
Diarrhea & 27 \\
Hemoptysis & 3 \\
\hline
\end{tabular}

\section{Discussion}

The previous studies have recorded that infection with helminths decreases the metabolic syndrome and diabetes in man [12], [13], [14].

Table 4: Stool examination of infected patients

\begin{tabular}{lll}
\hline Total patients (90) & & \\
\hline Category & Number of patients infected with parasites & $\%$ \\
\hline Asymptomatic patients & 1 & 0.01 \\
Mild symptoms & 0 & 0 \\
Severe disease & 0 & 0 \\
\hline
\end{tabular}

Parasitic infections provide immune tolerance by induction of secretion immunomodulatory cytokines (TGF $\beta$ and IL-10), and regulatory CD4+ $\mathrm{T}$ cells, and this may be the responsible key for the protection from COVID-19, in addition to that, severity of COVID-19 was recorded to be linked with activated pro-inflammatory condition that suppression by IL- 6 contrariness made improvement of clinical severity [15]. Parasites are developed and become sufficient modulators for human immunity, for instance, infection with schistosomiasis makes a balance between immune response type 1 and type 2 regarding cytokines (IL-13, IL-4, IL-5, and IFN $\gamma$ ) was very important to contain ova of some parasites in a small area of inflammation, and interleukin 10, that acts as immunoregulator that inhibits these responses to make immunopathology limitation [16].

Clinical outcomes of many researches were very higher worse in patients of COVID-19 with no parasites, and a high ratio of them was entered ICU, while existing helminth infections or protozoal infection 
is all related with reducing this probability [17].

Pre-existing parasitic infections provide prevention against pathogenesis related with COVID-19 severity, by perturbation of gut microbiome that results from parasitic infection which can change immune response to the infection of this virus. In animal models, researchers found that helminths protect lung from viral infections of it by acting together with microbiota [18].

\section{Conclusion}

There is inverse relationship between parasitic infection and COVID-19 infections, and it is significant to understand the action between parasites and microbiome, also its function in COVID-19 pathogenicity.

\section{References}

1. World Health Organization. Coronavirus Disease (COVID-19) Situation Report. Geneva: World Health Organization; 2020. p. 1-7. Available from: https://www.who.int/docs/default-source/ coronaviruse/situation-reports/20200707-covid-19-sitrep-169. pdf?sfvrsn=c6c69c88_2.

2. Zhou F, Yu T, Du R, Fan G, Liu Y, Liu Z, et al. Clinical course and risk factors for mortality of adult inpatients with COVID-19 in Wuhan, China: A retrospective study. Lancet. 2020;28(395):1054-62. https://doi.org/10.1016/s0140-6736(20)30566-3

PMid:32171076

3. Wu CY, Chen YC, Lee WI, Huang JL, Chen LC, Ou LS, et al. Risk factors associated with acute respiratory distress syndrome and death in patients with Coronavirus disease 2019 Pneumonia in Wuhan, China. JAMA Intern Med. 2020;180(7):934-43. https:// doi.org/10.1001/jamainternmed.2020.0994 PMid:32167524

4. Benzel F, Erdur H, Kohler S, Frentsch M, Thiel A, Harms L, et al. Immune monitoring of Trichuris suis egg therapy in multiple sclerosis patients. J Helminthol. 2012;86(3):339-47. https://doi. org/10.1017/s0022149x11000460

PMid:21838960

5. Herricks JR, Hotez PJ, Wanga V, Coffeng LE, Haagsma JA, Basáñez MG, et al. The global burden of disease study 2013: What does it mean for the NTDs? PLoS Negl Trop Dis. 2017;11(4):e0005424. https://doi.org/10.1371/journal. pntd. 0005424

PMid:28771480

6. Hotez PJ, Alvarado M, Basanez MG, Bolliger I, Bourne R, Boussinesq $\mathrm{M}$, et al. The global burden of disease study 2010: Interpretation and implications for the neglected tropical diseases. PLoS Negl Trop Dis. 2014;8(7):e2865. https://doi. org/10.1371/journal.pntd.0003135

PMid:25058013

7. Chabé M, Lokmer A, Ségurel L. Gut protozoa: Friends or foes of the human gut microbiota? Trends Parasitol.
2017;33(12):925-34. https://doi.org/10.1016/j.pt.2017.08.005 PMid:28870496

8. Siles-Lucas M, González-Miguel J, Geller R, Sanjuan R, Pérez-Arévalo J, Martínez-Moreno A. Potential influence of helminth molecules on COVID-19 pathology. Trends Parasitol. 2020;37(1):11-4. https://doi.org/10.1016/j.pt.2020.10.002 PMid:33153921

9. Ssebambulidde K, Segawa I, Abuga KM, Nakata V, Kayiira A, Ellis J, et al. Parasites and their Protection Against COVID-19: Ecology or Immunology? Med Rxiv; 2020. https://doi. org/10.1101/2020.05.11.20098053

10. McDermott MM, Spring B, Tian L, Treat-Jacobson D, Ferrucci L, Lloyd-Jones D, et al. Effect of low-intensity vs high-intensity home-based walking exercise on walk distance in patients with peripheral artery disease: The LITE randomized clinical trial. JAMA. 2021;325(13):1266-76. https://doi.org/10.1001/ jama.2021.2536

PMid:33821898

11. Wang D, Hu B, Hu C, Zhu F, Liu X, Zhang J, et al. Clinical characteristics of 138 hospitalized patients with 2019 novel Coronavirus-infected Pneumonia in Wuhan, China. JAMA. 2020;323(11):1061-9. https://doi.org/10.1001/jama.2020.1585 PMid:32031570

12. Sanya RE, Webb EL, Zziwa C, Kizindo R, Sewankambo M, Tumusiime $\mathrm{J}$, et al. The effect of helminth infections and their treatment on metabolic outcomes: Results of a clusterrandomized trial. Clin Infect Dis. 2020;71(3):601-3. https://doi. org/10.1093/cid/ciz859

PMid:31504336

13. Hays $R$, Pierce $D$, Giacomin $P$, Loukas $A$, Bourke $P$, McDermott R. Helminth co-infection and COVID-19: An alternate hypothesis. PLoS Negl Trop Dis. 2020;14(8):e0008628. https:// doi.org/10.1371/journal.pntd.0008628 PMid:32804930

14. Mbow M, Lell B, Jochems SP, Cisse B, Mboup S, Dewals BG et al. COVID-19 in Africa: Dampening the storm? Science. 2020;369(6504):624-6. https://doi.org/10.1126/science. abd3902

PMid:32764055

15. Zhang C, Wu Z, Li JW, Zhao H, Wang GQ. Cytokine release syndrome in severe COVID-19: Interleukin-6 receptor antagonist tocilizumab may be the key to reduce mortality. Int J Antimicrob Agents. 2020;55(5):105954. https://doi.org/10.1016/j. ijantimicag.2020.105954 PMid:32234467

16. Jenkins SJ, Hewitson JP, Jenkins GR, Mountford AP. Modulation of the host's immune response by schistosome larvae. Parasite Immunol. 2005;27(10-11):385-93. https://doi. org/10.1111/j.1365-3024.2005.00789.x PMid: 16179032

17. Margolin E, Burgers WA, Sturrock ED, Mendelson M, Chapman R, Douglass $\mathrm{N}$, et al. Prospects for SARSCoV-2 diagnostics, therapeutics and vaccines in Africa. Nat Rev Microbiol. 2020;18:690-704. https://doi.org/10.1038/ s41579-020-00441-3

18. McFarlane AJ, McSorley HJ, Davidson DJ, Fitch PM, Errington $\mathrm{C}$, Mackenzie $\mathrm{KJ}$, et al. Enteric helminth-induced Type I interferon signaling protects against pulmonary virus infection through interaction with the microbiota. J Allergy Clin Immunol. 2017;140(4):1068-78.e6. https://doi.org/10.1016/j. jaci.2017.01.016

PMid:28196762 